\title{
Application of Concrete Pros in Improving Science Learning Results Simple Electricity Circuit Material at Elementary School
}

\author{
Rudi Hartono \\ SD Negeri Malahayu 03 Brebes \\ rudihartono2122@gmail.com
}

\section{Article History}

received 3/12/2020

revised 17/12/2020

accepted $31 / 12 / 2020$

\begin{abstract}
This study aims to motivate and improve student achievement in grade VI SD Negeri Malahayu 03 in learning science about simple electrical circuits. The low evaluation results are usually related to student behavior during learning. For example, students often go in and out of class alternately, talk to themselves, and do not dare to ask questions to the teacher when they have difficulties. To achieve success in learning in a class, it is necessary to use appropriate learning methods and use of teaching aids. Teaching aids that encourage students to be active in the learning process of Natural Sciences are concrete teaching aids. Based on the data of grade VI students of SD Negeri Malahayu 03 who achieved the Minimum Completeness Criteria, from 44 students there were 19 students (43\%) in the pre-cycle to 31 students (71\%) in the first cycle and 40 students (100\%) in the second cycle. The conclusion of this study shows that learning with concrete media can improve science learning outcomes for grade VI students of SD Negeri Malahayu 03, Banjarharjo District, Brebes Regency in the first semester of the 2019/2020 school year.
\end{abstract}

Keywords: concrete media, learning outcomes, science

\begin{abstract}
Abstrak
Penelitian ini bertujuan untuk memotivasi dan meningkatkan prestasi belajar siswa kelas VI SD Negeri Malahayu 03 dalam pembelajaran IPA tentang rangkaian listrik sederhana. Rendahnya hasil evaluasi biasanya terkait dengan perilaku siswa saat pembelajaran berlangsung. Misalnya, siswa sering keluar masuk kelas secara bergantian, ngobrol sendiri, dan tidak berani menyampaikan pertanyaan kepada guru ketika mengalami kesulitan. Untuk mencapai keberhasilan dalam pembelajaran di suatu kelas, maka diperlukan metode pembelajaran dan penggunaan alat perga yang tepat. Alat peraga yang mendorong siswa aktif dalam proses pembelajaran IImu Pengetahuan Alam adalah alat perga yang konkrit. Berdasarkan data siswa kelas VI SD Negeri Malahayu 03 yang mencapai Kreteria Ketuntasan Minimal dari 44 siswa terdapat sebanyak 19 siswa (43\%) pada pra siklus menjadi 31 siswa (71\%) pada siklus I dan 40 siswa $(100 \%)$ pada siklus II.Sehingga kesimpulan penelitian ini menunjukkan bahwa pembelajaran dengan media konkrit dapat meningkatkan hasil belajar IPA siswa kelas VI SD Negeri Malahayu 03 Kecamatan Banjarharjo Kabupaten Brebes semester I tahun pelajaran 2019/2020.
\end{abstract}

Kata Kunci : media konkrit, hasil belajar, IPA

Social, Humanities, and Education Studies (SHEs): Conference Series https://jurnal.uns.ac.id/shes

p-ISSN 2620-9284 e-ISSN 2620-9292 


\section{PENDAHULUAN}

Proses belajar mengajar merupakan proses yang ditata dan diatur sedemikian rupa menurut langkah-langkah tertentu agar dalam pelaksanaannya dapat mencapai hasil yang diharapkan. Pengaturan tersebut biasanya tertuang dalam bentuk perangkat pembelajaran. Dengan demikain perangkat pembelajaran dapat dikatakan sebagai pedoman mengajar bagi guru dan pedoman belajar bagi siswa. Melalui perangkat pembelajaran dapat diidentifikasi apakah pembelajaran yang dilakukan sudah menerapkan konsep belajar siswa aktif atau mengembangkan pendekatan keterampilan proses.

Menurut Nazarudin (2007: 111) perangkat pembelajaran adalah segala sesuatu atau beberapa persiapan yang disusun oleh guru baik secara individu maupun berkelompok agar pelaksanaan dan evaluasi pembelajaran dapat dilakukan secara sistematis dan memperoleh hasil seperti yang diharapkan, sedangkan perangkat pembelajaran yang dimaksud terdiri atas Analisis Pekan Efektif, Program Tahunan, Program Semester, Silabus, Rencana Pelaksanaan Pembelajaran, dan Kriteria Ketuntasan Minimal. Sehingga perangkat pembelajaran merupakan acuan yang jelas, operasional, sistematis sebagai acuan guru dan siswa berdasarkan kurikulum yang berlaku.

Namun permasalahan dalam kelas tidak terkait satu persoalan, hal ini terjadi dalam praktek pembelajaran. Sesuatu yang telah direncanakan kadang hasilnya tidak sesuai dengan harapan. Hal ini yang menjadi penyebab perlunya guru melakukan refleksi atas pembelajaran yang telah dilakukan dan belum mencapai tujuan yang telah ditetapkan. Sebagimana yang telah dialami penulis di kelas VI SD Negeri Malahayu 03 Kecamatan Banjarharjo Kabupaten Brebes mengalami masalah dalam mencapai ketuntasan belajar siswa khususnya pada mata pelajaran IImu Pengetahun Alam Kompetensi Dasar Mengidentifikasi komponen-komponen listrik dan fungsinya dalam rangkaian listrik sederhana. Hal ini dapat dilihat dari hasil evaluasi siswa. Dari 44 siswa kelas VI yang mengikuti evaluasi hanya 19 (43\%) siswa yang memperoleh nilai lebih dari 65 atau yang mencapai kreteria ketuntasan minimal (KKM).

Rendahnya hasil evaluasi siswa ini terkait dengan perilaku siswa saat pembelajaran berlangsung. Misalnya, siswa sering keluar masuk kelas secara bergantian, ramai dan ngobrol sendiri, pasif dalam kegiatan pembelajaran, kurang memperhatikan penjelasan guru, tidak berani menyampaikan pertanyaan kepada guru ketika mengalami kesulitan dan kurang kompak dalam penugasan secara kelompok.

Dari berbagai masalah di atas, diketahui bahwa proses pembelajaran IImu Pengetahun Alam di kelas VI SD Negeri Malahayu 03 kecamatan Banjarharjo kabupaten Brebes, kurang efektif. Kekurang efektifan tersebut karena penjelasan guru kurang menarik, guru tidak menggunakan alat peraga, guru tidak menghirukan siswa yang berbicara sendiri, dan guru tidak mengaitkan IImu Pengetahuan Alam dengan lingkungan sekitar.

Berdasarkan identifikasi masalah di atas, analisis masalahanya adalah guru tidak menggunakan alat peraga dalam pembelajaran. Menurut Wijaya \& Rusyan [1994] yang dimaksud Alat Peraga Pendidikan adalah media pendidikan berperan sebagai perangsang belajar \& dapat menumbuhkan motivasi belajar sehingga siswa tidak menjadi bosan dalam meraih tujuan - tujuan belajar. Menurut Nasution [1985] alat peraga pendidikan adalah alat pembantu dalam mengajar agar efektif. Menurut Sudjana [2009] Pengertian Alat Peraga Pendidikan adalah suatu alat yang dapat diserap oleh mata \& telinga dengan tujuan membantu guru agar proses belajar mengajar siswa lebih efektif \& efisien. Dan menurut Faizal [2010] Alat Peraga Pendidikan sebagai instrument audio maupun visual yang digunakan untuk membantu proses pembelajaran menjadi lebih menarik \& membangkitkan minat siswa dalam mendalami suatu materi. Maka pemecahan masalahnya adalah guru harus menggunakan alat peraga supaya pembelajaran tidak membosankan. 
Dengan dasar di atas, maka penulis melakukan beberapa perbaikan pembelajaran dengan melakukan Penelitian Tindakan Kelas, melalui rumusan masalah apakah dengan menggunakan alat peraga yang konkrit dapat meningkatkan pemahaman siswa kelas VI SD Negeri Malahayu 03 kecamatan Banjarhajo kabupaten Brebes dalam pembelajaran IImu Pengetahuan Alam dengan kompetensi Dasar Menjelaskan hubungan antara sumber daya alam dengan lingkungan?

Penelitian ini bertujuan untuk memotivasi dan meningkatkan prestasi belajar siswa kelas VI SD Negeri Malahayu 03 dalam pembelajaran IPA tentang rangkaian listrik sederhana.

Hasil penelitian yanag dilakukan penulis mempunayai manfaat yang cukup besar yakni manfaat bagi siswa, guru, maupun bagi sekolah. Bagi siswa yaitu dapat meningkatkan minat siswa dalam mempelajari sumber daya alam, meningkatkan prestasi belajar siswa, bertambahnya keaktifan siswa dalam proses pembelajaran, dan melatih siswa berpikir realitas terhadap hasil belajarnya. Manfaat bagi guru yaitu meningkatkan prestasi guru dalam kegiatan belajar mengajar dalam pembelajaran IPA, dapat memperbaikai pembelajaran yang dikelolanya, guru lebih percaya diri untuk mengembangkan kepropesionalannya, guru menyadari pentingnya penggunaan alat peraga dalam pembelajaran, guru mendapat keterampilan dalam memberikan motivasi belajar siswa, guru memperoleh materi untuk menulis makalah mengenai mengatasi masalah belajar siswa. Adapun manfaat bagi sekolah yaitu meningkatkan kualitas pendidikan untuk para siswa, tersedianya tenaga guru profesional, sekolah mempunyai kesempatan untuk berkembang lebih pesat, dan dapat menjadi acuan bagi lembaga pendidikan lainnya.

\section{METODE}

Penelitian ini merupakan Penelitian Tindakan Kelas (PTK). Peneliti melaksanakan Penelitian Tindakan Kelas (PTK) pada siswa kelas VI SDN Malahayu 03 Kecamatan Banjarharjo, Kabupaten Brebes tahun pelajaran 2019/2020. Peneliti menggunakan desain Model Kemmis dan Mc. Taggart yang memiliki 4 tahap. Tahapanya yaitu sebagai berikut: planning, acting, observing, dan reflecting. (Wiriaatmadja, 2005, hlm. 66). Partisipan dalam penelitian ini adalah peserta didik kelas VI SDN Malahayu 03 yang terdiri dari 44 peserta didik dengan peserta didik laki-laki berjumlah 20 orang dan perempuan berjumlah 24 orang.

Sebelum melaksanakan Penelitian Tindakan Kelas ( PTK) dengan menerapkan penggunaan alat peraga konkrit, terlebih dulu peneliti melakukan observasi awal pra siklus. Pra siklus dilaksanakan pada tanggal 6 November 2019. Berdasarkan hasil temuan yang ditemukan dari data hasil observasi awal pra siklus yang berupa hasil observasi aktivitas siswa dan guru serta hasil belajar IPA, peneliti melaksanakan penelitian dengan menerapkan penggunaan alat peraga konkrit dalam dua siklus. Siklus 1 dilaksanakan pada tanggal 13 November 2019 dan siklus 2 dilaksanakan pada tanggal 20 November 2019. Instrumen yang digunakan yaitu lembar observasi aktivitas guru dengan siswa dan soal tes evaluasi. Teknik pengumpulan data yang digunakan yaitu Teknik tes dan non tes. Teknik analisis data yang digunakan adalah deskriptif kualitatif dan kuantitatif.

\section{HASIL DAN PEMBAHASAN}

Dari data kualitas perbaikan pembelajaran dan hasil tes formatif siswa yang ditemukan dalam penelitian di kelas VI Sekolah Dasar Negeri Malahayu 03 Kecamatan Banjarharjo Kabupaten Brebes dapat dikatakan bahwa pelaksanaan perbaikan pembelajaran meningkat dan prestasi belajar siswa juga meningkat. Peningkatan prestasi belajar siswa kelas VI Sekolah Dasar Negeri Malahayu 03 Kecamatan 
Banjarharjo Kabupaten Brebes terjadi dalam pelaksanaan perbaikan pembelajaran berjalan dengan baik.

Sebelum melaksanakan Penelitian Tindakan Kelas ( PTK) dengan menerapkan penggunaan alat peraga konkrit, terlebih dulu peneliti melakukan observasi awal pra siklus. Pra siklus dilaksanakan pada tanggal 6 November 2019. Berdasarkan hasil temuan yang ditemukan dari data hasil observasi awal pra siklus yang berupa hasil observasi aktivitas siswa dan guru serta hasil belajar IImu Pengetahuan Alam, peneliti melaksanakan penelitian dengan menerapkan penggunaan alat peraga konkrit dalam dua siklus. Siklus 1 dilaksanakan pada tanggal 13 November 2019 dan siklus 2 dilaksanakan pada tanggal 20 November 2019. Instrumen yang digunakan yaitu lembar observasi aktivitas guru dengan siswa dan soal tes evaluasi. Teknik pengumpulan data yang digunakan yaitu Teknik tes dan non tes. Teknik analisis data yang digunakan adalah deskriptif kualitatif dan kuantitatif.

Data hasil belajar siswa pra siklus, siklus 1 dan siklus 2 yang dilakukan peneliti dapat dilihat pada tabel di bawah ini :

Tabel 1. Perbandingan Hasil Belajar Siswa pada Prasiklus, Siklus I dan Siklus II

\begin{tabular}{|c|c|c|c|c|c|c|c|}
\hline \multirow{2}{*}{ Nilai } & \multirow{2}{*}{ Keterangan } & \multicolumn{2}{|c|}{ Prasiklus } & \multicolumn{2}{|c|}{ Siklus I } & \multicolumn{2}{|c|}{ Siklus II } \\
\hline & & $\mathbf{F}$ & $\mathbf{P}(\%)$ & $\mathbf{F}$ & $\mathbf{P}(\%)$ & $\mathbf{F}$ & $\mathbf{P}(\%)$ \\
\hline$\geq 70$ & Tuntas & 19 & 43 & 31 & 71 & 40 & 91 \\
\hline$\leq 70$ & Tidak Tuntas & 25 & 57 & 13 & 29 & 4 & 9 \\
\hline \multicolumn{2}{|c|}{ Jumlah } & 44 & 100 & 44 & 100 & 44 & 100 \\
\hline \multicolumn{2}{|c|}{ Rata-rata } & \multicolumn{2}{|c|}{50} & \multicolumn{2}{|c|}{70} & \multicolumn{2}{|c|}{85} \\
\hline \multicolumn{2}{|c|}{ Minimum } & \multicolumn{2}{|c|}{42} & \multicolumn{2}{|c|}{70} & \multicolumn{2}{|c|}{70} \\
\hline \multicolumn{2}{|c|}{ Maksimal } & \multicolumn{2}{|c|}{72} & \multicolumn{2}{|c|}{85} & \multicolumn{2}{|c|}{100} \\
\hline
\end{tabular}

Keterangan :

$$
\begin{aligned}
& F=\text { Frekuensi } \\
& P=\text { Persentase }
\end{aligned}
$$

\section{Pra Siklus}

Berdasarkan tabel 1 terlihat bahwa hasil belajar siswa pada tahap pra siklus yang ditinjau dari ketuntasan belajar, nilai minimum, nilai maksimum dan nilai rata- rata dari pra siklus pada pembelajaran IImu Pengetahuan Alam siswa yang tuntas dan memenuhi Kriteria Ketuntasan Minimal berjumlah 19 siswa dengan presentase 43\% dan siswa yang belum tuntas berjumlah 25 siswa dengan presentase $57 \%$. Berdasarkan data hasil belajar siswa mata pelajaran IImu Pengetahuan Alam pada pra siklus yang menunjukkan belum memenuhi ketuntasan klasikal, peneliti menerapkan penggunaan alat peraga konkrit dalam pembelajaran IImu Pengetahuan Alam. Peneliti merancang perangkat pembelajaran pada Kompetensi Dasar 3.4 Mengidentifikasi komponenkomponen listrik dan fungsinya dalam rangkaian listrik sederhana. Kemudian membuat lembar observasi aktivitas guru dan siswa serta soal tes evaluasi siswa.

\section{Siklus 1}

Siklus 1 dilaksankan pada tanggal 13 November 2019. Peneliti menerapkan penggunaan alat peraga konkrit pada pembelajaran IImu Pengetahuan Alam Kompetensi Dasar 3.4 Mengidentifikasi komponen-komponen listrik dan fungsinya dalam rangkaian listrik sederhana.

Berdasarkan tabel 1, dapat dilihat bahwa hasil belajar siswa pada pembelajaran Ilmu Pengetahuan Alam mengalami peningkatan dari pra siklus. Pada siklus 1 siswa 
yang tuntas dan memenuhi Kriteria Ketuntasan Minimal berjumlah 31 siswa dengan presentase $71 \%$ dan siswa yang belum tuntas berjumlah 13 siswa dengan presentase $29 \%$. Berdasarkan hasil refleksi siklus 1 memutuskan untuk melanjutkan siklus 2 karena belum memenuhi ketuntasan klasikal yang diharapkan.

\section{Siklus 2}

Siklus 2 dilaksankan pada tanggal 20 November 2019. Peneliti menerapkan penggunaan alat peraga konkrit pada pembelajaran IImu Pengetahuan Alam Kompetensi Dasar 3.4 Mengidentifikasi komponen-komponen listrik dan fungsinya dalam rangkaian listrik sederhana.

Berdasarkan tabel 1, dapat dilihat bahwa hasil belajar siswa pada pembelajaran Ilmu Pengetahuan Alam mengalami peningkatan dari siklus 1. Pada siklus 2 siswa yang tuntas dan memenuhi Kriteria Ketuntasan Minimal berjumlah 40 siswa dengan presentase $91 \%$ dan siswa yang belum tuntas berjumlah 4 siswa dengan presentase $9 \%$.

Hasil belajar siswa pada pra siklus, siklus 1 dan siklus 2 selalu mengalami peningkatan dan pada siklus 2 sudah memenuhi ketuntasan klasikal yang diharapkan. Peningkatan presentase ketuntasan hasil belajar siswa dapat dilihat pada gambar 1

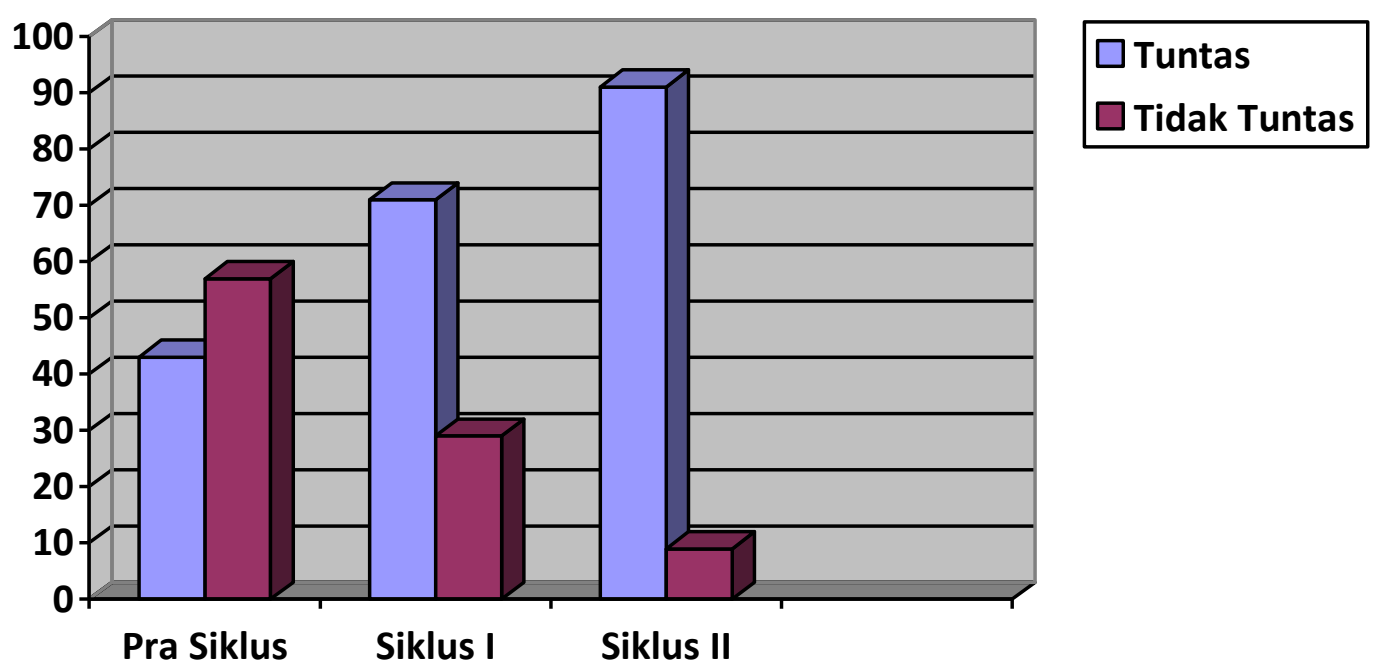

Gambar 1. Perbandingan Hasil Belajar Siswa pada Prasiklus, Siklus I dan Siklus II

Berdasarkan gambar 1, terlihat bahwa Pembelajaran menerapkan penggunaan alat peraga berhasil meningkatkan hasil belajar IImu Pengetahuan Alam kelas VI Sekolah Dasar Negeri Malahayu 03 Kecamatan Banjarharjo, Kabupaten Brebes semester I tahun pelajaran 2019/2020, terlihat hasil belajar IImu Pengetahuan Alam siswa kelas VI Sekolah Dasar Negeri Malahayu 03 selalu mengalami peningkatan pada setiap siklus dan pada akhir siklus 40 siswa sudah mencapai Kriteria Ketuntasan Minimal dengan presentase $91 \%$ dan hanya 4 siswa yang tidak memenuhi Kriteria Ketuntasan Minimal dengan presentase 9\%. Ini menunjukkan bahwa sudah memenuhi ketuntasan klasikal yang diharapkan.

Peningkatan prestasi belajar siswa kelas VI Sekolah Dasar Negeri Malahayu 03 Kecamatan Banjarharjo Kabupaten Brebes terjadi dalam pelaksanaan perbaikan pembelajaran berjalan dengan baik. Penulis melaksanakan aktivitas-aktivitas dengan menggunakan metode yang tepat. Adapun aktifitas-aktifitas tersebut adalah meliputi:

1) Pemberian apersepsi yang menarik 
Guru menunjukkan kepada siswa komponen-komponen listrik sederhana kemudian siswa diminta untuk menyebutkan nama benda tersebut.

2) Penggunaan alat peraga yang bervariasi

Pada siklus I guru menggunakan alat peraga yang berupa gambar, sehingga siswa masih bingung dalam membuat rangkaian listrik sederhana. Sedangkan pada siklus II guru menggunakan alat peraga yang berupa benda konkrit (nyata), sehingga siswa tidak bingung dalam membuat rangkaian listrik sederhana.

3) Keterlibatan siswa dalam penggunaan alat peraga

Setiap peraga yang digunakan selalu melibatkan siswa dengan maksud agar siswa mengalami sendiri apa yang diinginkan dalam proses pembelajaran, sehingga pembelajaran lebih bermakna

4) Pengaktifan siswa dalam mendemonstrasikan alat peraga

Pada siklus I guru mendemonstrasikan sendiri alat peraga yang ada, siswa hanya melihat dan mengamati sehingga siswa masih bingung dalam membuat rangkaian listriksederhana. Sedangkan pada siklus II siswa memperagakan sendiri alat peraga yang ada secara berkelompok sehingga siswa dapat membuat rangkaian listrik sederhana.

\section{SIMPULAN}

Dari hasil-hasil penelitian, dapat disimpulkan bahwa perbaikan pembelajaran IImu Pengetahuan Alam pada Kompetensi Dasar 3.4 Mengidentifikasi komponen-komponen listrik dan fungsinya dalam rangkaian listrik sederhana di kelas VI Sekolah Dasar Negeri Malahayu 03, Kecamatan Banjarharjo, Kabupaten Brebes berjalan dengan baik. Hal ini dapat terbukti pada peningkatan nilai siswa mulai dari pra siklus, siklus I dan siklus II. Dengan penggunaan alat peraga konkrit jumlah siswa mendapat nilai sesuai KKM sebanyak 19 siswa (43\%) pada pra siklus menjadi 31 siswa (71\%) pada siklus I dan 40 siswa $(91 \%)$ pada siklus II. Disamping nilai kuantitas yang meningkat juga jumlah kualitaspun rata-rata meningkat dari 50 pada pra siklus, 70 pada siklus I dan 85 pada siklus II.

Peningkatan prestasi siswa juga dipengaruhi karena penulis melaksanakan aktivitas berupa pemberian apersepsi menarik, penggunaan alat peraga yang konkrit, keterlibatan siswa dalam menggunakan alat peraga, pengaktifan siswa dalam pemberian tugas mendemonstrasikan media pembelajaran.

Bertolak dari hasil-hasil penelitian yang diperoleh, penulis menyampaikan saran kepada rekan-rekan guru dalam pembelajaran IImu Pengetahuan Alam, guru hendaknya menggunakan alat peraga konkrit (nyata) sehingga materi tersampaikan dengan baik. Disamping itu, berdasarkan pengalaman yang penulis alami alangkah baiknya jika penelitian tindakan kelas (PTK) dapat dilaksanakan disetiap sekolah.

\section{DAFTAR PUSTAKA}

Nazarudin. (2007). Manajemen Pembelajaran: Implementasi Konsep, Karakteristik dan Metodologi Pendidikan Agama Islam di Sekolah Umum. Yogyakarta: Teras

Wijaya, Cece \& Tabrani Rusyan.(1994). Kemampuan Guru Dalam Proses Belajar Mengajar. Bandung: Remaja rosdakarya

Nasution. (1985). Alat Peraga dalam Pembelajaran. Jakarta: Rineka Cipta.

Sudjana, Nana. (2009). Dasar- Dasar Proses Belajar Mengajar. Bandung: Sinar Baru Algensido.

Faizal. (2010). Pengertian dan Tujuan Alat Peraga.chttp://pengertiandantujuanalatperaga.com, diakses 5 april 2013

Wiriaatmadja. (2005). Metode Penelitian Tindakan Kelas. Bandung: Remaja Rosdakarya.

Andayani, dkk. (2011). Pemantapan Kemampuan Profesional. Jakarta: Universitas Terbuka. 
Hadiat, dkk. (2004). Sains. Jakarta : Erlangga.

Haryanto, dkk. (2004). Sains. Jakarta : Erlangga.

Hermawan, Asep Henry. (2008). Pengembangan Kurikulum dan Pembelajaran. Jakarta: Pusat Penerbit Universitas Terbuka.

I.G.A.K. Wardani, Siti Julaekha, Nudi Marsinah. (2008). Penelitian Tindakan Kelas. Jakarta : Universitas Terbuka.

Suprayekti, dkk. (2007). Pembaharuan Pembelajaran di SD. Jakarta: Universitas Terbuka.

Winataputra, Udin S. (2003). Strategi Belajar Mengajar. Jakarta : Universitas Terbuka. 